\title{
Early mammary gland metabolic and immune responses during natural-like and forceful drying-off in high-yielding dairy cows
}

\author{
Nissim Silanikove, ${ }^{*}$ Uzi Merin, $†$ Fira Shapiro, ${ }^{*}$ and Gabriel Leitnerł \\ *Biology of Lactation Laboratory, Institute of Animal Science, ARO, the Volcani Center, PO Box 6, Bet Dagan 50250, Israel \\ †Department of Food Quality and Safety, Postharvest and Food Sciences, ARO, the Volcani Center, PO Box 6, Bet Dagan 50250, Israel \\ $\ddagger$ National Mastitis Center, Kimron Veterinary Institute, PO Box 12, Bet Dagan 50250, Israel
}

\begin{abstract}
The present work compared metabolic and immune responses in genetically high-producing cows that produced a low amount of milk before expected involution and in cows with the same genetic potential that produced copious amounts of milk before their scheduled drying-off. Ten multiparous lactating Israeli Holstein cows producing approximately $10,500 \mathrm{~L}$ in the current lactation, without bacterial infection and scheduled for drying-off approximately $60 \mathrm{~d}$ before their expected parturition, were studied. Five of the cows that exhibited a sharp, spontaneous reduction in milk yield at the end of their lactation and produced less than $\sim 14 \mathrm{~L} / \mathrm{d}$ were defined as cows approaching natural involution (ANI), and 5 cows that produced between 25 and 35 L/d were defined as cows approaching forced involution (AFI). Three days before scheduled drying-off, milking was stopped and milk samples were collected from each quarter. After milking cessation, only modest swelling was observed in the udders of the ANI cows. In the ANI cows, lactose and fat concentrations decreased and the fat:lactose concentration ratio indicated that on $\mathrm{d} 1$ and 2 fat concentrations decreased faster than lactose concentration, whereas on $\mathrm{d} 3$, the rate of reduction was about the same for lactose and fat. In contrast, in AFI cows, fat concentrations increased on d 1 and the fat:lactose ratio indicated that changes in fat secretion were minor compared with those of lactose secretion. Rennet clotting time of milk after drying-off in the ANI cows increased, whereas curd firmness decreased rapidly, such that mammary secretions did not coagulate on $\mathrm{d}$ 3. In the AFI cows, such significant changes were observed only on $\mathrm{d} 3$. The inflammatory response increased in both groups, but at each stage the increase was greater in ANI cows than in AFI cows. On d 1, the increase in leukocyte numbers in the ANI cows was
\end{abstract}

Received February 28, 2013.

Accepted July 1, 2013.

${ }^{1}$ Corresponding author: nsilanik@agri.huji.ac.il made up of mononuclear cells (i.e., T lymphocytes and macrophages). In contrast, in the AFI cows, we observed a marked increase in leukocyte numbers, mainly in the form of polymorphonuclear cells. Our data indicate that the abrupt mammary involution induced in AFI cows provoked signs of distress, which were associated with neutrophilia in milk. In contrast, in the ANI cows, cessation of milking occurred without evidence of engorgement of the udder. Physiological differences in ANI and AFI cows are distinct and are reflected in the differences in the leukocyte populations in milk.

Key words: involution, mammary gland, adaptation, acute response

\section{INTRODUCTION}

Most of the development of the mammary glands occurs at the end of pregnancy and to a much lesser extent after parturition. After weaning, the glands regress to their prelactating state (Atabai et al., 2007). The first stage of involution (stage I), which comprises the events occurring between drying-off (induction of milk stasis) and extensive degradation of the secretory tissues, is associated with widespread apoptosis of the alveolar epithelial cells (Lund et al., 1996).

Involution of the mammary gland in most mammals under natural conditions begins when their offspring either stop suckling or reduce the frequency of suckling. However, most of the relevant research in bovine and mice was carried out by induction of abrupt involution (Capuco and Akers, 1999; Clarkson et al., 2004), probably because this procedure is quite easy to manipulate and carry out under controlled conditions. However, there is no evidence to indicate that results from abrupt cessation of milking necessarily reflect changes occurring during natural involution. Recent evidence in mice suggests that abruptly induced involution resembles the course of wound healing (Clarkson et al., 2004).

The classical view, however, is that involution of the mammary glands is an orderly, programmed physiological process (Monks et al., 2002; Nilsen-Hamilton et al., 2003). In mice and bovines, natural mammary 
gland involution is associated with immunomodulatory responses that are essential for clearing the apoptotic cells and preventing new infection (Capuco and Akers, 1999). Thus, although there is no doubt that mammary gland involution is associated with activation of the immune system, the question remains whether it is an orderly tissue-remodeling process or a process that includes elements of acute (e.g., wound healing) inflammation during gradual or natural-like involution.

Most cows in modern dairy herds are separated from their offspring soon after giving birth and inseminated during the next 80 to $100 \mathrm{~d}$. Consequently, unlike most wildlife and many farm animal species, pregnancy and lactation occur simultaneously in cows, while lactation is preserved by milking. Despite these changes in management, previous reports led us to hypothesize that when cows with a high genetic potential for milk production produce less milk $(<15 \mathrm{~L} / \mathrm{d})$ toward the end of lactation, it might reflect a preserved metabolic adaptation toward the expected involution of the mammary gland that typically occurs at the end of the lactation cycle. The intensive selection of modern cows for high milk yield and persistency allows induction of abrupt involution at the end of lactation, whereas, in some cows, this procedure is less acute due to metabolic adaptation (Silanikove et al., 2005; Leitner et al., 2011, 2012). This unique situation in dairy cows allows comparison between abrupt and natural-like involution at the same stage of lactation and with low within-group variability in terms of milk yield.

The aims of the present experiment were to test the following hypotheses: (1) that involution of the mammary glands in cows undergoing natural-like involution (sudden cessation of milking in late-lactating cows with high genetic potential for milk yield but producing low amounts of milk toward drying-off) is preceded by metabolic and immunological adaptations; and (2) that the involution induced in nonadapted cows (sudden cessation of milking in high-producing cows) is distressing and distinctly different from that in cows undergoing natural-like involution.

\section{MATERIALS AND METHODS}

\section{Animals, Management, and Experimental Setup}

The experiment was carried out with 10 multiparous lactating Israeli Holstein cows (in their second and third lactations) at $301 \pm 6 \mathrm{~d}$ in lactation (i.e., $\sim 60$ $\mathrm{d}$ before expected parturition) that were scheduled for drying-off treatment (cessation of milking to induce involution). The experiment was carried out during December with average maximal ambient temperature of $20 \pm 4^{\circ} \mathrm{C}$ and average minimal temperatures of $7 \pm 3^{\circ} \mathrm{C}$.
Throughout their lactation, cows were fed a typical Israeli TMR that comprised $65 \%$ concentrates and $35 \%$ forage and contained $17 \%$ protein. The estimated $\mathrm{NE}_{\mathrm{L}}$ was $1.56 \mathrm{Mcal} / \mathrm{kg}$ and it was based on the estimated TDN from feed analysis (provided by the feed supplier) at $3 \times$ maintenance intake using NRC (2001) prediction equations.

At entering drying-off, feed changed to $35 \%$ concentrates and $65 \%$ forage, and contained $13.5 \%$ protein. The cows were milked thrice daily, at 0500, 1300, and $2000 \mathrm{~h}$, and their milk yield was automatically recorded (Leitner et al., 2006).

In the present lactation, the milk yield of all enrolled cows was $10,490 \pm 650 \mathrm{~L}$, which was very similar to the average farm yield of $10,520 \pm 520 \mathrm{~L}$ over $305 \mathrm{~d}$. The mammary glands of all enrolled cows were ascertained as being free of bacterial infection, as previously described (Leitner et al., 2006). The health history and lactation curves of the enrolled cows were closely monitored to ensure that their milk yield at the start of the experiment was not influenced by health problems such as acute mastitis and lameness.

Five of the cows exhibited a sharp, spontaneous reduction in milk yield at the end of their lactation and produced $<14 \mathrm{~L} / \mathrm{d}$ and were defined as cows approaching natural-like involution (ANI), and 5 cows that produced between 25 and $35 \mathrm{~L} / \mathrm{d}$ were defined as cows approaching forced involution (AFI).

Three days before scheduled drying-off, milking was stopped and milk samples were collected from each quarter of each enrolled cow by evacuating the whole gland on $\mathrm{d} 0$ (before last milking) and 1,2, and $3 \mathrm{~d}$ thereafter by hand milking. Following the last sampling, all cows were dried off and received antibiotic treatment (cefquinome, $150 \mathrm{mg}$; Intervet, Boxmeer, the Netherlands), as practiced by the herd veterinarian (Leitner et al., 2006). In addition, milk from 3 cows in mid lactation (156 $\pm 55 \mathrm{~d})$ was used to obtain values on the antibacterial properties of normal (mid lactation) and bacteria-free milk. These cows had SCC of $75 \pm 7$ $\times 10^{3}$ cells $/ \mathrm{mL}$ and were free of bacterial infection.

All protocols were approved by the Institutional Animal Care Committee of the Agricultural Research Organization (Bet Dagan, Israel), which is the legitimate body for such authorizations in Israel.

\section{Sampling and Laboratory Procedures}

Representative samples ( 100 mL) of mammary gland secretions were taken from the whole yield of each gland (i.e., 5 cows $\times 4$ glands/cow $\times 4$ samples taken on d $0,1,2$, and $3=80$ glands per treatment) during the morning milking. Analytical procedures that used antibodies were performed in duplicate, whereas all the 
other procedures were carried out in triplicate. Whole milk samples were analyzed within $12 \mathrm{~h}$ as follows: one aliquot was used for the determination of curd firmness and rennet clotting time by the Optigraph (Ysebaert, Frepillon, France; Merin et al., 2008), SCC determined by Fossomatic 360 (Foss Electric, Hillerød, Denmark), and differentiation of somatic cells by flow cytometry (FACS Calibur, Becton Dickinson Immunocytometry System, San Jose, CA; Leitner et al., 2011) using antibovine monoclonal antibodies (VMRD Inc., Pullman, WA). The following monoclonal antibodies were used: anti-CD18/11a (BAT 75A; IgG 1 ), anti-CD4 (GC 50A1 138A; IgM), anti-CD8 (CACT 80C; IgG $_{1}$ ), anti-CD14 (CAM 36A; $\operatorname{IgG}_{1}$ ), and anti-polymorphonuclear (G1; IgM). The following secondary polyclonal antibodies (Caltag Laboratories, Burlingame, CA) were used: goat anti-mouse IgG-1 conjugated with Tri-Color and goat anti-mouse IgM conjugated with fluorescein isothiocyanate (FITC). The amount and proportion of epithelial cells in mammary secretion was evaluated as the difference between SCC and the number of total leukocytes $\left(\mathrm{CD} 18^{+}\right.$cells) in the sample (Leitner et al., 2011). Apoptosis of the PMNL was analyzed by means of annexin $\mathrm{V}$ staining using a commercial kit (BD Bioscience, Detection Kit I, provided by Bactlab Diagnostics, Caesarea, Israel) according to the manufacturer's instructions. Consequently, cells were considered active if they were positive to their specific monoclonal antibody and negative to annexin. Preserved samples were analyzed for lactose, fat, and total protein in the central laboratory of the Israel Cattle Breeders Association (Caesarea, Israel) with Milkoscan FT6000 (Foss Electric, Dublin, Ireland).

A second aliquot of the samples was defatted and analyzed according to previously described methodologies for the activity of plasmin (PL), plasmin activator (PA), and plasminogen (PLG; Silanikove et al., 2009), concentrations of casein and proteose peptone (Silanikove et al., 2000), nitrite and lactoferrin (Silanikove et al., 2005), albumin (Shamay et al., 2005), lactate, malate, citrate, and lactate dehydrogenase (LDH) activity by fluorimetric methods (Larsen, 2005; Shapiro and Silanikove, 2010; Silanikove and Shapiro, 2011). Mammary secretions were prepared for $\mathrm{Na}$ and K analysis as described by Shamay et al. (2000), and the concentrations of these minerals were measured by using inductively coupled plasma-atomic emission spectrometry (Spectro, Kleve, Germany).

A third aliquot of each sample was used to analyze the antibacterial properties of mammary secretion by a recently modified procedure (Silanikove et al., 2011). Milk from the 3 mid-lactating cows (reference samples) and the samples from the ANI and AFI cows were defatted at $4^{\circ} \mathrm{C}$ and the casein was removed by ultracentrifugation to prevent interference of casein in the optical density (OD) measurements that were applied to quantify bacterial growth capacity (Silanikove and Shapiro, 2011). The supernatant (clear whey) was sterilized by passing it through a $0.22-\mu \mathrm{m}$ filter. The kinetics of growth of pathogenic Escherichia coli P4 strain (Bramley, 1976) was evaluated in the sterilized whey samples. Bacteria were cultured in nutrient agar with $5 \%$ washed sheep erythrocytes. Before the assay, bacteria were grown in peptone water for $4 \mathrm{~h}$. The number of bacteria was adjusted with peptone water to 1 $\times 10^{8} \mathrm{cfu} / \mathrm{mL}$ using a previously established standard curve (OD against colony-forming units) and finally adjusted to a working concentration of $1 \times 10^{5} \mathrm{cfu} /$ $\mathrm{mL}$. Then, $200 \mu \mathrm{L}$ of each whey sample was aseptically distributed and inoculated with $20 \mu \mathrm{L}$ of bacterial culture in duplicate in round-bottomed-well microplates (Immuno 96 MicroWell Solid Plates, Thermo Fisher Scientific, Slangerup, Denmark). Samples without inoculation were distributed along the plates for negative controls. The OD of these samples served as blanks and their average OD value was subtracted from the OD of standards and samples. The plates were incubated in a microplate reader (Tecan GENios Plus, Männedorf, Switzerland) prewarmed for $20 \mathrm{~h}$ at $37^{\circ} \mathrm{C}$. Optical density at $492 \mathrm{~nm}$ was read every 20 min after orbital shaking for $10 \mathrm{~s}$. Each experiment was carried out in triplicate.

The following data were used to analyze bacterial growth: lag time was obtained from the individual growth curves and defined as the time point that immediately preceded the first significant increase (by $t$-test analysis) in OD recording $(P<0.05)$. The biological half-life time $\left(\mathbf{T}_{1 / 2}\right)$ of bacterial growth was calculated as follows: OD values were transformed to their respective $\ln$ values and were used as the dependent variable in a regression analysis against the respective time points $(\mathrm{n}=65, \mathrm{r}=0.95$ to $0.98 ; P<0.0001)$. The $\mathrm{T}_{1 / 2}$ time of bacterial growth was calculated as 0.693 (ln 2 )/ $\mathrm{k}$ (the slope of the regression line), which was obtained from the linear regression analysis. Bacterial growth at the stationary phase was presented as fraction of bacterial growth in milk sampled from the AFI cows at time 0. The stationary phase time was calculated as $1 / \mathrm{k}$.

\section{Statistical Analysis}

Data were analyzed using repeated-measures analysis modeling correlated residuals within cow as described before (SAS Institute, 1988; Shamay et al., 2003). Briefly, the analysis considered the effects of treatment, day, and treatment $\times$ day interactions. The effect of 
quarter sampling within cow class effect was not significant $(P>0.25)$; therefore, data on the quarter level are not reported. Analysis of data on somatic cells and leukocyte types was carried out after transforming counts to $\log _{10}$, and analysis of their percentages of total SCC was carried out on the ratio of their $\log _{10}$-transformed values.

Model [1] was

$$
Y_{i j k m}=\mu+C_{i}+T_{j}+T_{j} D_{k}+Q_{m}\left(T_{j} C_{i}\right)+e_{i j k m},[1]
$$

where $Y_{i j k m}=$ variable within cow, treatment, quarter, and day; $\mu=$ mean; $C_{i}=$ cow class effect; $T_{j}=$ treatment class effect; $D_{k}=$ day class effect; $T_{j} D_{k}=$ treatment $\times$ day interaction effect; $Q_{m}\left(T_{j} C_{i}\right)=$ quarter within cow treatment error term for treatment effect; and $e_{i j k m}=$ residual error.

Comparison between lag time and $\mathrm{T}_{1 / 2}$ time of bacterial growth between milk sampled at time 0 (before drying-off) in control, ANI, and AFI cows and at d 1,2 , and 3 after drying-off in ANI and AFI cows was done by a 2-way ANOVA model in a repeated-measure design where the examined effects were source of milk (treatment) and sampling time (model [2]):

$$
Y_{i j k l}=\mu+\alpha_{i}+e_{i j}+\lambda_{k}+\alpha \lambda_{i k}+e_{i j k l}
$$

where $Y_{i j k l}=$ dependent variable, $\mu=$ overall mean, $\alpha_{i}$ $=$ effect of the $i$ th treatment (fixed effect), $e_{i j}=$ variance between samples within treatment (error 1), $\lambda_{k}=$ effect of the $k$ th time (fixed effect), $\alpha \lambda_{i k}=$ interaction between treatment and time, and $e_{i j k l}=$ random error.

In both models, multiple comparisons between days of both groups were made applying the Tukey-Kramer honestly significant difference (HSD) $t$-test, considering $P<0.05$ as the minimal acceptable significance level.

\section{RESULTS}

\section{Milk Yield and Gross Composition}

Milk yield (on a whole-udder basis) of ANI cows on d $0(9.2 \pm 0.8 \mathrm{~L} / \mathrm{d})$, was lower $(P<0.001)$ than that of AFI cows $(28.8 \pm 1.6 \mathrm{~L} / \mathrm{d})$. After milking was stopped, only modest swelling was observed in the udders of the ANI cows. In contrast, the glands of the AFI cows, particularly in the first $2 \mathrm{~d}$, were markedly engorged, which was associated with secretion leakage and vocalization, suggesting that the cows were in pain.

Lactose concentration on d 0 was $6 \%$ lower $(P<$ 0.05 ) in ANI than in AFI cows (Table 1). After dryingoff, lactose concentration decreased faster in ANI than in AFI cows, resulting in $34.5 \%$ lower values in ANI cows on d 3 compared with the pre-drying-off level ( $P$ $<0.001)$ but only $24 \%$ lower $(P<0.05)$ than that in the AFI cows.

Before drying-off, the concentrations of fat and protein were higher $(P<0.05)$ in the milk of ANI cows than in the AFI cows (Table 1). After drying-off, fat concentration in the ANI cows decreased, and the fat:lactose concentration ratio indicated that, on $\mathrm{d} 1$ and 2 , fat concentration decreased faster than lactose concentration, whereas on $\mathrm{d} 3$, the rate of reduction was about the same for lactose and fat. In contrast, during the $3 \mathrm{~d}$ after drying-off, fat concentration in the AFI cows was higher than on $\mathrm{d} 0$ and the fat:lactose ratio indicated that changes in fat secretion were minor compared with those of lactose secretion. Protein concentration increased in both groups but more dramatically in the AFI cows, in which it almost doubled (Table 1). The protein:lactose ratio indicated that the rate of the decrease in protein secretion was lower than the decrease in lactose secretion, particularly in the ANI cows compared with the AFI cows.

Table 1. Milk composition (lactose, fat, and total protein; mean \pm SE) of cows approaching natural involution (ANI) or forceful involution (AFI) before the induction of involution (milking cessation) and during the first $3 \mathrm{~d}$ after the induction of involution ${ }^{1}$

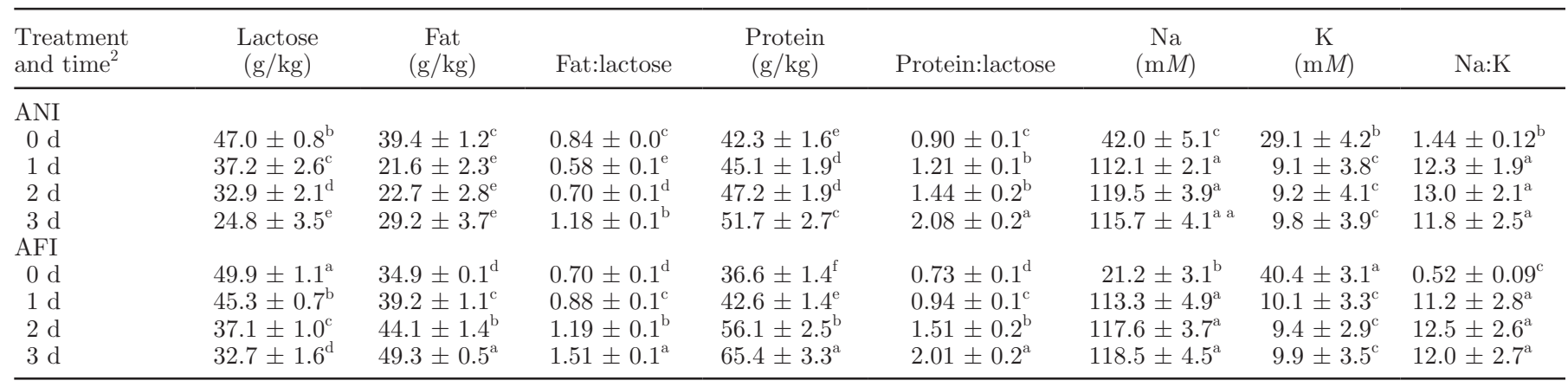

\footnotetext{
${ }^{\mathrm{a}-\mathrm{e}}$ Values within a column with no common superscript differ significantly, ranked from highest to lowest values $(P<0.05)$.

${ }^{1}$ Treatment and time effects were significant $(P<0.01)$ for all parameters, whereas cow effects were not significant.

${ }^{2}$ Time $0 \mathrm{~d}=$ samples taken before drying-off (involution); $1,2,3 \mathrm{~d}=$ time after milking cessation.
} 

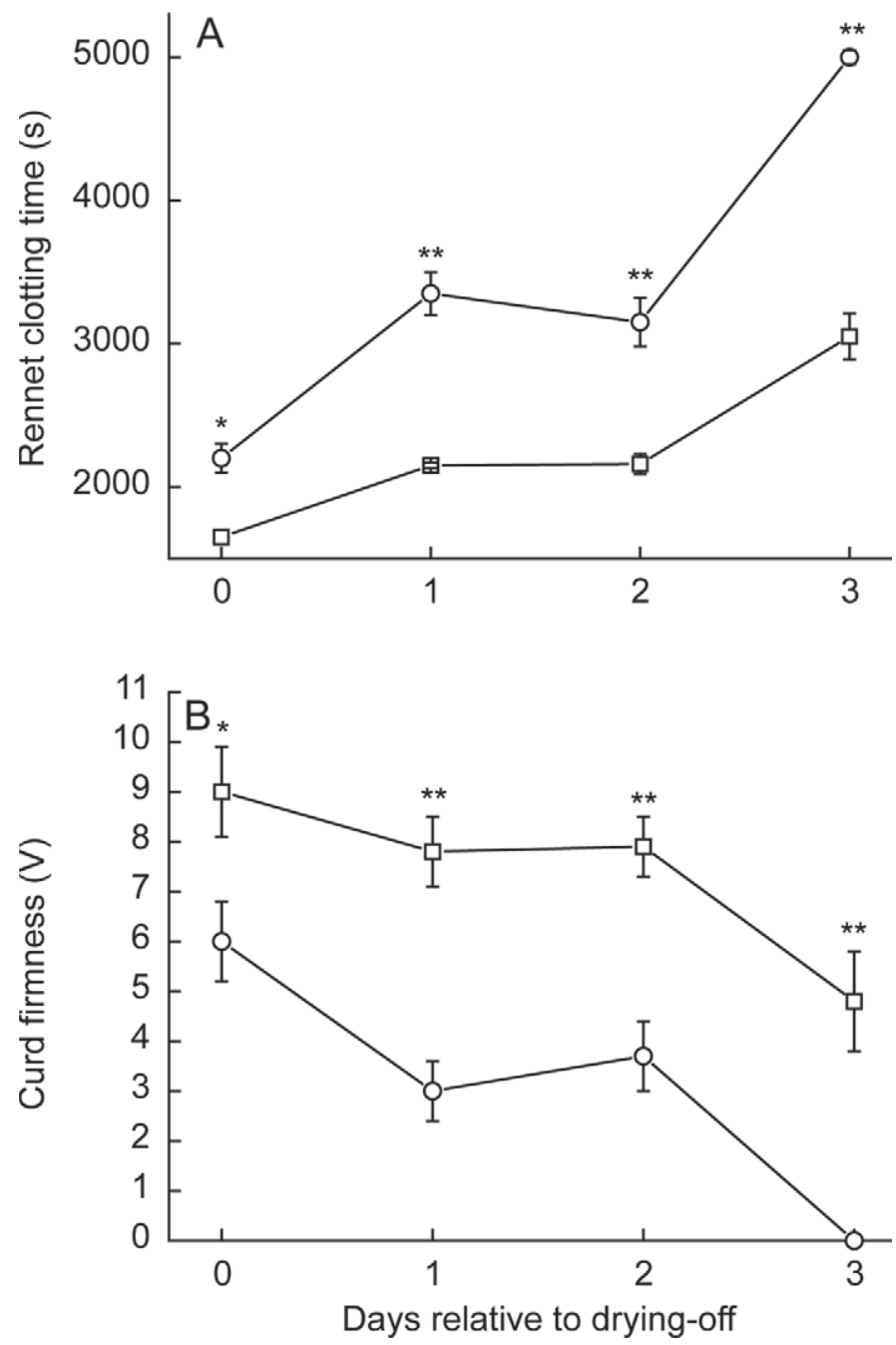

Figure 1. Rennet clotting time (A) and curd firmness (B) in milk of cows approaching natural involution (ANI; O) or forced involution (AFI; $\square$ ) before milk cessation (d 0) and during the first $3 \mathrm{~d}$ after milking cessation (mean $\pm \mathrm{SE}$ ). Rennet clotting time and curd firmness between ANI and AFI cows on d 0 were significant $\left({ }^{*} P<0.05\right)$ and increased $(* * P<0.01)$ on the following days. Rennet clotting time and curd firmness calculated from the drying-off values between ANI and AFI cows were significant $(P<0.001$ and $P<0.05$, respectively).

\section{Na and K Concentrations in Milk}

The concentration of $\mathrm{Na}^{+}$was higher in the ANI than in AFI cows on $\mathrm{d} 0(P<0.01 ; 42 \pm 5$ vs. $21 \pm 3$ $\mathrm{m} M)$, whereas that of $\mathrm{K}^{+}$was lower in the ANI cows $(P<0.01 ; 29 \pm 4$ vs. $40 \pm 4 \mathrm{mM}$; Table 1$)$. From d 1 on, dramatic changes occurred in the concentration of monovalent ions (increase of $\mathrm{Na}^{+}$and decrease of $\mathrm{K}^{+}$) in the mammary secretions of both groups, so that their concentrations resembled the normal concentration of their blood plasma $\left(\mathrm{Na}^{+}: 119 \pm 9\right.$ and $\left.\mathrm{K}^{+}: 9 \pm 4 \mathrm{mM}\right)$.

\section{Milk Coagulation, Plasmin System, and Formation of Proteose Peptone}

Rennet clotting time on d 0 was longer and curd firmness was lower in ANI than in AFI cows $(P<$ $0.05)$ and increased $(P<0.01)$ on the days following drying-off (Figure 1, panels A and B). After drying-off, rennet clotting time increased, whereas curd firmness decreased rapidly in the ANI cows; on d 3, mammary secretions did not coagulate at all (Figure 1, panel B). In the AFI cows, significant changes in rennet clotting time and curd firmness $(P<0.05)$ compared with $\mathrm{d}$ 0 were observed only on d 3 after drying-off and were smaller in AFI than in ANI cows $(P<0.001$; Figure 1 , panels $\mathrm{A}$ and $\mathrm{B}$ ).

Activities of PA, measured by the amounts of PLG converted to PL (as reflected by lower PLG:PL ratio), and PL on $\mathrm{d} 0$ were higher in ANI than in AFI cows $(P<0.05$; Table 2). Drying-off in the ANI cows was associated with increased conversion of PLG to PL and PL activity, although PA activity was not increased and even decreased on $\mathrm{d} 3$. In contrast, in the AFI cows, PA activity increased modestly only on d 3 after drying-off $(P<0.01$; Table 2$)$.

Proteose peptone concentration was higher in ANI than in AFI cows on d $0(P<0.05$; Table 2). After drying-off, proteose peptone concentration increased from d 0 to $\mathrm{d} 3$ in the ANI cows, linearly related to the increase in PL activity $(P<0.001)$ and rennet clotting time $(P<0.001)$ and in an inverse linear relation to curd firmness $(P<0.01)$ as calculated from the data in Figure 1. In the AFI cows, a more modest increase in proteose peptone concentration in milk was observed only on d $3(P<0.01$ between treatments; Table 2$)$. However, the interrelationships between proteose peptone concentration and PL and between proteose peptone and milk rennet clotting time or curd firmness were similar in both groups $(\mathrm{n}=160 ; \mathrm{r}=0.8,0.8$, and 0.9 , respectively; $P<0.001)$.

\section{Measures of Metabolic Activity in Milk}

Lactate and malate concentrations on d 0 were higher in milk of ANI cows than in that of AFI cows $(P$ $<0.05$; Table 3), whereas citrate concentrations were similar. After drying-off, the concentrations of lactate and malate in ANI cows increased with time, whereas citrate concentrations decreased on $\mathrm{d} 3$. In the AFI cows, no significant change in the concentrations of lactate and citrate was observed, but the concentration of malate increased after drying-off. Consequently, the citrate:(lactate + malate) concentration ratio before drying-off decreased in the ANI cows $(P<0.001)$, 
Table 2. Activity (mean $\pm \mathrm{SE}$ ) of plasminogen activator (PA), plasminogen (PLG), and plasmin (PL) and the concentration of proteose peptone in cows approaching natural involution (ANI) or forceful involution (AFI) before the induction of involution (milk cessation) and during the first $3 \mathrm{~d}$ after the induction of involution ${ }^{1}$

\begin{tabular}{|c|c|c|c|c|c|}
\hline $\begin{array}{l}\text { Treatment } \\
\text { and time }\end{array}$ & $\begin{array}{c}\mathrm{PA} \\
\left(\mathrm{U}^{3} / \mathrm{mL}\right)\end{array}$ & $\begin{array}{c}\text { PLG } \\
(\mathrm{U} / \mathrm{mL})\end{array}$ & $\begin{array}{c}\mathrm{PL} \\
(\mathrm{U} / \mathrm{mL})\end{array}$ & PLG:PL & $\begin{array}{l}\text { Proteose peptone } \\
\qquad(\mathrm{mg} / \mathrm{mL})\end{array}$ \\
\hline \multicolumn{6}{|l|}{ ANI } \\
\hline $0 \mathrm{~d}$ & $443 \pm 14^{\mathrm{a}}$ & $147 \pm 9^{\mathrm{a}}$ & $32 \pm 6^{\mathrm{b}}$ & $4.60 \pm 0.5^{\mathrm{b}}$ & $1.01 \pm 0.1^{\mathrm{b}}$ \\
\hline $1 \mathrm{~d}$ & $423 \pm 13^{\mathrm{a}}$ & $144 \pm 12^{\mathrm{a}}$ & $36 \pm 6^{\mathrm{b}}$ & $4.01 \pm 0.5^{\mathrm{b}}$ & $1.21 \pm 0.1^{\mathrm{a}}$ \\
\hline $2 \mathrm{~d}$ & $418 \pm 53^{\mathrm{a}}$ & $142 \pm 8^{\mathrm{a}}$ & $39 \pm 6^{\mathrm{b}}$ & $3.61 \pm 0.6^{\mathrm{b}}$ & $1.32 \pm 0.1^{\mathrm{a}}$ \\
\hline $3 \mathrm{~d}$ & $272 \pm 9^{c}$ & $94 \pm 9^{\mathrm{b}}$ & $66 \pm 7^{\mathrm{a}}$ & $1.42 \pm 0.5^{\mathrm{c}}$ & $1.55 \pm 0.1^{\mathrm{a}}$ \\
\hline \multicolumn{6}{|l|}{ AFI } \\
\hline $0 \mathrm{~d}$ & $352 \pm 23^{\mathrm{b}}$ & $131 \pm 10^{\mathrm{a}}$ & $22 \pm 6^{\mathrm{c}}$ & $5.95 \pm 0.5^{\mathrm{a}}$ & $0.86 \pm 0.1^{\mathrm{c}}$ \\
\hline $1 \mathrm{~d}$ & $345 \pm 27^{\mathrm{b}}$ & $128 \pm 9^{\mathrm{a}}$ & $23 \pm 5^{\mathrm{c}}$ & $5.56 \pm 0.6^{\mathrm{a}}$ & $0.85 \pm 0.1^{\mathrm{c}}$ \\
\hline $2 \mathrm{~d}$ & $298 \pm 28^{\mathrm{c}}$ & $136 \pm 10^{\mathrm{a}}$ & $18 \pm 3^{\mathrm{c}}$ & $7.55 \pm 0.7^{\mathrm{a}}$ & $0.87 \pm 0.1^{\mathrm{c}}$ \\
\hline $3 \mathrm{~d}$ & $363 \pm 16^{b}$ & $127 \pm 10^{\mathrm{a}}$ & $33 \pm 12^{\mathrm{b}}$ & $3.85 \pm 0.6^{\mathrm{b}}$ & $1.03 \pm 0.1^{\mathrm{b}}$ \\
\hline
\end{tabular}

${ }^{\mathrm{a}-\mathrm{c}}$ Values within a column with no common superscript differ significantly, ranked from highest to lowest values $(P<0.05)$.

${ }^{1}$ Treatment and time effects were significant $(P<0.01)$ for all parameters, whereas cow effects were not significant.

${ }^{2}$ Time $0 \mathrm{~d}$ = samples taken before drying-off (involution); 1, 2, $3 \mathrm{~d}=$ time after milking cessation.

${ }^{3} \mathrm{U}=$ activity unit; 1 unit is the amount of PA, PLG, or PL that produces a change in absorbance of 0.1 at $405 \mathrm{~nm}$ in $60 \mathrm{~min}$.

whereas it was maintained at a higher level in the AFI cows during the experiment (Table $3 ; P<0.05$ between groups before drying-off and $P<0.001$ after dryingoff).

\section{Indicators of Inflammation and Immune Components in Milk}

After drying-off, the concentration of nitrite and $\mathrm{LDH}$ activity increased in the ANI cows; in the AFI cows, an increase in LDH activity was noted from d 2 after drying-off, the increase being smaller than in the ANI cows $(P<0.01$; Table 3$)$. Activity of LDH was higher in the ANI than AFI cows on d $0(P<0.05)$.
Lactoferrin and albumin concentrations on $\mathrm{d} 0$ were higher in ANI than in AFI cows $(P<0.05$; Table 3$)$. After drying-off, the concentrations of lactoferrin and albumin increased with time in the ANI cows, but not in the AFI cows $(P<0.01$; Table 3$)$.

\section{Milk Leukocyte Population}

Somatic cell counts on d 0 were higher in ANI than in AFI cows $(P<0.05)$. After drying-off, SCC increased in both groups, but at each stage the increase was greater in the ANI cows $(P<0.01)$. The numbers and proportions of different leukocytes are presented in Table 4 and Figure 2. Total leukocytes $\left(\mathrm{CD} 18^{+}\right.$cells) of SCC

Table 3. Concentrations (mean $\pm \mathrm{SE}$ ) of lactate, malate, citrate, nitrite, lactoferrin, and albumin and activity of lactate dehydrogenase in milk of cows approaching natural involution (ANI) or forceful involution (AFI) before the induction of involution (milk cessation) and during the first $3 \mathrm{~d}$ after the induction of involution ${ }^{1}$

\begin{tabular}{|c|c|c|c|c|c|c|c|c|}
\hline $\begin{array}{l}\text { Treatment } \\
\text { and time }\end{array}$ & $\begin{array}{l}\text { Lactate } \\
(\mu M)\end{array}$ & $\begin{array}{l}\text { Malate } \\
(\mu M)\end{array}$ & $\begin{array}{l}\text { Citrate } \\
(\mathrm{m} M)\end{array}$ & $\begin{array}{l}\text { Citrate:(lactate } \\
\quad+\text { malate) }\end{array}$ & $\begin{array}{l}\text { Nitrite } \\
(\mu M)\end{array}$ & $\begin{array}{c}\text { Lactate } \\
\text { dehydrogenase } \\
(\mathrm{U} / \mathrm{mL})\end{array}$ & $\begin{array}{l}\text { Lactoferrin } \\
(\mu \mathrm{g} / \mathrm{mL})\end{array}$ & $\begin{array}{l}\text { Albumin } \\
(\mu \mathrm{g} / \mathrm{mL})\end{array}$ \\
\hline \multicolumn{9}{|l|}{ ANI } \\
\hline $1 \mathrm{~d}$ & $248 \pm 40^{\mathrm{b}}$ & $356 \pm 41^{\mathrm{b}}$ & $11.0 \pm 1^{\mathrm{a}}$ & $18.2 \pm 2.5^{\mathrm{c}}$ & $372 \pm 31^{\mathrm{ab}}$ & $444 \pm 58^{b}$ & $610 \pm 49^{\mathrm{b}}$ & $425 \pm 49^{c}$ \\
\hline $2 \mathrm{~d}$ & $287 \pm 52^{\mathrm{b}}$ & $306 \pm 46^{\mathrm{b}}$ & $10.1 \pm 1^{\mathrm{a}}$ & $17.0 \pm 2.3^{\mathrm{cb}}$ & $541 \pm 99^{\mathrm{a}}$ & $544 \pm 99^{\mathrm{b}}$ & $990 \pm 53^{\mathrm{a}}$ & $795 \pm 51^{\mathrm{b}}$ \\
\hline $3 \mathrm{~d}$ & $511 \pm 28^{\mathrm{a}}$ & $864 \pm 79^{\mathrm{a}}$ & $8.0 \pm 2^{\mathrm{b}}$ & $5.8 \pm 1.3^{\mathrm{d}}$ & $663 \pm 65^{\mathrm{a}}$ & $1.699 \pm 30^{\mathrm{a}}$ & $1,215 \pm 63^{\mathrm{a}}$ & $1,110 \pm 62^{\mathrm{a}}$ \\
\hline \multicolumn{9}{|l|}{ AFI } \\
\hline $2 \mathrm{~d}$ & $147 \pm 13^{\mathrm{c}}$ & $239 \pm 15^{b}$ & $14.1 \pm 1^{\mathrm{a}}$ & $36.5 \pm 2.6^{\mathrm{a}}$ & $233 \pm 22^{\mathrm{b}}$ & $267 \pm 6^{\mathrm{c}}$ & $187 \pm 43^{\mathrm{d}}$ & $175 \pm 41^{\mathrm{d}}$ \\
\hline $3 \mathrm{~d}$ & $122 \pm 9^{\mathrm{c}}$ & $255 \pm 69^{\mathrm{b}}$ & $14.0 \pm 1^{\mathrm{a}}$ & $37.1 \pm 2.3^{\mathrm{a}}$ & $300 \pm 31^{\mathrm{ab}}$ & $478 \pm 38^{\mathrm{b}}$ & $182 \pm 49^{\mathrm{d}}$ & $174 \pm 51^{\mathrm{d}}$ \\
\hline
\end{tabular}

\footnotetext{
${ }^{\mathrm{a}-\mathrm{d}}$ Values within a column with no common superscript differ significantly, ranked from highest to lowest values $(P<0.05)$.

${ }^{1}$ Treatment and time effects were significant $(P<0.01)$ for all parameters, whereas cow effects were not significant.

${ }^{2}$ Time $0 \mathrm{~d}=$ samples taken before drying-off (involution); $1,2,3 \mathrm{~d}=$ time after milking cessation.
} 
Table 4. Counts (mean $\pm \mathrm{SE} ; \times 10^{3}$ cells $/ \mathrm{mL}$ ) of somatic cells $(\mathrm{SCC})$, total leukocytes $\left(\mathrm{CD} 18^{+}\right)$, neutrophils (PMNL), lymphocytes $\left(\mathrm{CD} 4^{+}\right.$and $\left.\mathrm{CD} 8^{+}\right)$and macrophages $\left(\mathrm{CD} 14^{+}\right)$in milk of cows approaching natural involution (ANI) or forceful involution (AFI) before the induction of involution (milk cessation) and during the first $3 \mathrm{~d}$ after the induction of involution ${ }^{1}$

\begin{tabular}{|c|c|c|c|c|c|c|}
\hline $\begin{array}{l}\text { Treatment } \\
\text { and time }\end{array}$ & SCC & $\mathrm{CD} 18^{+}$ & PMN & $\mathrm{CD} 4^{+}$ & $\mathrm{CD}^{+}$ & $\mathrm{CD} 14^{+}$ \\
\hline \multicolumn{7}{|l|}{ ANI } \\
\hline $0 \mathrm{~d}$ & $182 \pm 77^{\mathrm{c}}$ & $86 \pm 27^{\mathrm{d}}$ & $37 \pm 12^{\mathrm{c}}$ & $9 \pm 4^{\mathrm{c}}$ & $20 \pm 7^{\mathrm{c}}$ & $8 \pm 3^{\mathrm{d}}$ \\
\hline $1 \mathrm{~d}$ & $650 \pm 172^{\mathrm{b}}$ & $588 \pm 164^{\mathrm{b}}$ & $182 \pm 56^{\mathrm{b}}$ & $83 \pm 23^{\mathrm{b}}$ & $140 \pm 45^{\mathrm{ab}}$ & $82 \pm 19^{\mathrm{b}}$ \\
\hline $2 \mathrm{~d}$ & $744 \pm 198^{\mathrm{d}}$ & $685 \pm 194^{\mathrm{b}}$ & $399 \pm 96^{\mathrm{b}}$ & $48 \pm 17^{\mathrm{b}}$ & $98 \pm 44^{\mathrm{b}}$ & $85 \pm 26^{\mathrm{b}}$ \\
\hline $3 \mathrm{~d}$ & $1,873 \pm 632^{\mathrm{a}}$ & $1,626 \pm 539^{\mathrm{a}}$ & $999 \pm 342^{\mathrm{a}}$ & $152 \pm 46^{\mathrm{a}}$ & $243 \pm 76^{\mathrm{a}}$ & $327 \pm 88^{\mathrm{a}}$ \\
\hline \multicolumn{7}{|l|}{ AFI } \\
\hline $0 \mathrm{~d}$ & $78 \pm 25^{\mathrm{d}}$ & $53 \pm 21^{\mathrm{d}}$ & $39 \pm 19^{c}$ & $5 \pm 2^{\mathrm{c}}$ & $6 \pm 3^{\mathrm{d}}$ & $6 \pm 3^{\mathrm{d}}$ \\
\hline $1 \mathrm{~d}$ & $248 \pm 39^{\mathrm{c}}$ & $227 \pm 33^{\mathrm{cd}}$ & $203 \pm 31^{\mathrm{b}}$ & $3 \pm 1^{\mathrm{c}}$ & $1 \pm 1^{\mathrm{d}}$ & $10 \pm 3^{\mathrm{d}}$ \\
\hline $2 \mathrm{~d}$ & $479 \pm 95^{\mathrm{bc}}$ & $414 \pm 88^{\mathrm{bc}}$ & $382 \pm 94^{\mathrm{b}}$ & $3 \pm 1^{\mathrm{c}}$ & $1 \pm 1^{\mathrm{d}}$ & $29 \pm 5^{\mathrm{c}}$ \\
\hline $3 \mathrm{~d}$ & $903 \pm 179^{\mathrm{b}}$ & $750 \pm 171^{\mathrm{b}}$ & $615 \pm 129^{\mathrm{ab}}$ & $11 \pm 4^{\mathrm{c}}$ & $2 \pm 1^{\mathrm{d}}$ & $61 \pm 16^{\mathrm{b}}$ \\
\hline
\end{tabular}

${ }^{a-d}$ Values within a column with no common superscript differ significantly, ranked from highest to lowest values $(P<0.05)$.

${ }^{1}$ Treatment and time effects were significant $(P<0.01)$ for all parameters, whereas cow effects were not significant.

${ }^{2}$ Time $0 \mathrm{~d}=$ samples taken before drying-off (involution); $1,2,3 \mathrm{~d}=$ time after milking cessation

were higher in ANI than in AFI cows before dryingoff. After drying-off, the number of total leukocytes steadily increased in the ANI cows and reached $>85 \%$ of the SCC on d 3. On d 1, the increase in leukocyte number in the ANI cows was made up of mononuclear cells (i.e., T lymphocytes and macrophages; Figure 2, panels $\mathrm{B}, \mathrm{C}$, and $\mathrm{D}$ ) and a moderate increase in PMNL (Figure 2A). In contrast, in the AFI cows, we observed a marked increase in leukocyte number on $\mathrm{d} 1$, mainly in the form of PMNL, which reached $93 \%$ of total SCC. In all cows, the number of B cells was negligible through the experiment.

The proportion of live PMNL (annexin-negative PMNL) was about the same $(\sim 23 \%)$ in the ANI and AFI cows before drying-off. After drying-off, the percentage of live PMNL remained constant on $\mathrm{d} 1$ and 2 in the AFI cows and decreased to $\sim 15 \%$ on $\mathrm{d} 3$. In contrast, in the ANI cows, the percentage of live PMN increased to $\sim 50 \%$ on $\mathrm{d} 1(P<0.01)$ and remained $>35 \%$ on $\mathrm{d} 2$ and $3(P<0.01$; data not shown $)$.

\section{Antibacterial Activity of Mammary Secretions}

The lag time required for the start of bacterial growth in milk before drying-off was longer in the ANI cows than in the control cows (at mid-lactation) or the AFI cows. Bacterial growth in milk samples from ANI cows was lower compared with that of the control and AFI cows $(P<0.05$; Table 5). After drying-off, the lag time of bacterial growth increased from day to day so that on d 3 after drying-off, bacterial growth in mammary secretions sampled from the ANI cows $\left(\mathrm{T}_{1 / 2}\right.$ of bacterial growth) increased by $\sim 35 \%$ compared with that on $\mathrm{d}$ 0 . In the AFI cows, significant changes in lag time and growth rate were recorded only in milk sampled on $\mathrm{d} 3$, reaching a level recorded in the ANI cows before drying $(P<0.01$ for differences between treatments; Table 5$)$.

Bacterial growth at the stationary phase at time 0 in the AFI cows did not differ from the values recorded in mid-lactation cows with bacteria-free milk (reference values) by the paired $t$-test analysis. Bacterial growth in the stationary phase at time 0 was $20 \%$ lower in the ANI cows than in the AFI cows $(P<0.05$; Table 5$)$. After induction of involution, bacterial growth in the stationary phase decreased in ANI cows from day to day and on $\mathrm{d} 3$ it was $50 \%$ lower than in the AFI cows on $\mathrm{d} 0(P<0.01$; Table 5$)$. In the AFI cows, bacterial growth rate became lower than on d 0 only on d 3, reaching the level recorded in the ANI cows on $\mathrm{d} 0$ (Table 5).

\section{DISCUSSION}

In this paper, we provide novel data indicating that the involution process in dairy cows critically depends on the conditions that precede drying-off. Involution in cows that produce low amounts of milk before drying-off (ANI) is associated with metabolic and immunological features that allow the cows to clear effectively apoptotic cells and eradicate or prevent new infections. On the other hand, involution in cows that produce copious amounts of milk before drying-off (AFI) is associated with distress responses and a less effective ability to fight bacterial invasion into the udder. In general, our results coincide with those of Piantoni et al. (2010), who showed that when Holstein cows were milked $1 \times$ daily instead of $2 \times$ daily until complete cessation of milking, it was associated with alterations in metabolic 

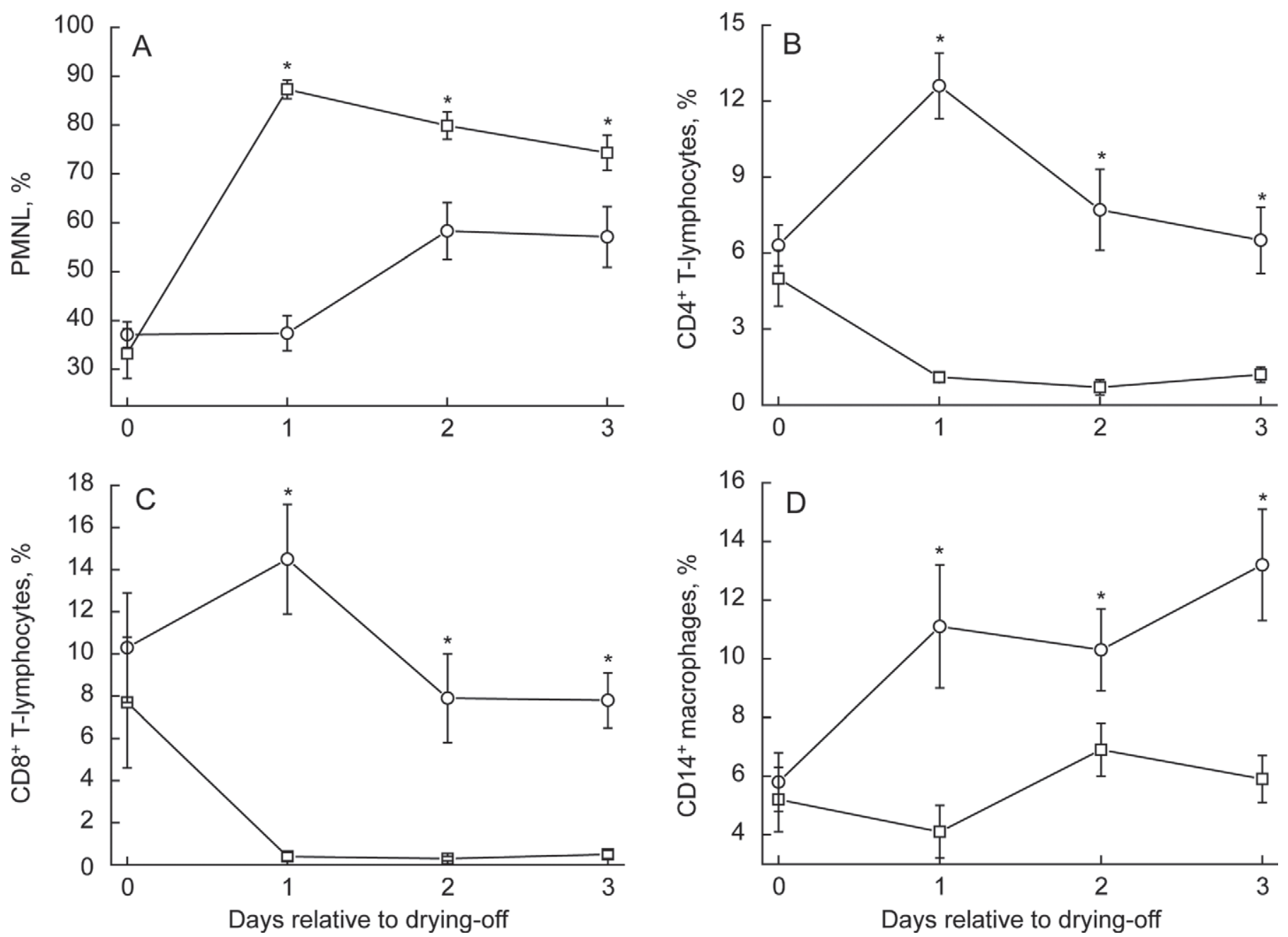

Figure 2. The proportion (\%) of PMNL (A), CD4 $4^{+}$T-lymphocytes (B), CD8 ${ }^{+}$T-lymphocytes (C), and CD14 ${ }^{+}$macrophages (D) in milk of cows approaching natural involution (ANI; O) or forced involution (AFI; $\square$ ) before milking cessation (d 0 ) and during the first $3 \mathrm{~d}$ after milking cessation (mean $\pm \mathrm{SE}$ ). Proportions of each type of cell were significantly different $\left({ }^{*} P<0.05\right)$ between ANI and AFI cows on d 1 to 3 .

and cell survival mechanisms of mammary gland cells, which were induced partly via oxidative stress-triggered inflammation and a decline in metabolic activity.

\section{Abrupt Involution Induces Distress and Ineffective Antibacterial Immune Responses}

Abrupt involution induced in AFI cows provoked responses of distress, which were associated with neutrophilia in milk. Similar responses were also observed in beef cows when abruptly weaned (Lynch et al., 2010). In addition, modern dairy cows are usually induced into involution by abrupt cessation of milking while still producing considerable amounts of milk (20, 40, and even $50 \mathrm{~L} / \mathrm{d}$ ). Such a practice results in the accumulation of massive amounts of milk in the udder, which leads to udder engorgement and milk leakage and frequently to vocalization for several days, probably due to pain (Leitner et al., 2007b).

The influx of neutrophils to injured or infected sites forms the first line of the immunological defense (Chuang et al., 2009). Thus, the question arises of why abrupt involution induces such urgent responses. Typically, between 20 and $40 \%$ of the mammary glands in modern dairy cows are infected with bacteria (Hillerton et al., 2007). Thus, disruption of the tight junction represents a threat for their penetration to the blood (bacteremia), where they can cause life-threatening conditions. It has long been known that casein is a potent inflammatory mediator that induces the chemotactic migration of neutrophils when injected into mice tissues (Metcalf et al., 1996). Casein hydrolysates (e.g., proteose peptone) are present in milk (as shown in this study) and induce chemotactic migration of leukocytes 
Table 5. Bacteriostatic activity (increase in lag time and increase in biological half-life time $\left(\mathrm{T}_{1 / 2}\right)$ of bacterial growth; mean $\pm \mathrm{SE}$ ) toward pathogenic Escherichia coli $\mathrm{P} 4$ strain in skim milk sampled from cows approaching natural involution (ANI) or forceful involution (AFI) before the induction of involution (milk cessation) and during the first $3 \mathrm{~d}$ after the induction of involution ${ }^{1}$

\begin{tabular}{lccc}
\hline $\begin{array}{l}\text { Treatment } \\
\text { and time }\end{array}$ & $\begin{array}{c}\text { Lag time } \\
(\mathrm{h})\end{array}$ & $\begin{array}{c}\mathrm{T}_{1 / 2} \text { of bacterial } \\
\text { growth }(\mathrm{h})\end{array}$ & $\begin{array}{c}\text { Bacterial growth } \\
\text { in stationary phase }\end{array}$ \\
\hline $\begin{array}{l}\text { Reference milk } \\
\text { ANI }\end{array}$ & $9.8 \pm 1.1$ & $6.1 \pm 0.6$ & $1.1 \pm 0.1$ \\
$0 \mathrm{~d}$ & $11.5 \pm 0.8^{\mathrm{b}}$ & $9.2 \pm 0.6^{\mathrm{c}}$ & $0.8 \pm 0.1^{\mathrm{b}}$ \\
$1 \mathrm{~d}$ & $12.2 \pm 0.7^{\mathrm{b}}$ & $9.8 \pm 0.7^{\mathrm{b}}$ & $0.7 \pm 0.1^{\mathrm{b}}$ \\
$2 \mathrm{~d}$ & $12.6 \pm 1.1^{\mathrm{b}}$ & $11.5 \pm 0.8^{\mathrm{b}}$ & $0.6 \pm 0.1^{\mathrm{bc}}$ \\
$3 \mathrm{~d}$ & $13.3 \pm 0.8^{\mathrm{c}}$ & $12.4 \pm 0.9^{\mathrm{a}}$ & $0.5 \pm 0.1^{\mathrm{c}}$ \\
AFI & & & \\
$0 \mathrm{~d}$ & $9.9 \pm 1.1^{\mathrm{a}}$ & $6.2 \pm 11^{\mathrm{d}}$ & $1.0 \pm 0.2^{\mathrm{a}}$ \\
$1 \mathrm{~d}$ & $10.3 \pm 0.9^{\mathrm{a}}$ & $6.3 \pm 12^{\mathrm{d}}$ & $0.9 \pm 0.2^{\mathrm{a}}$ \\
$2 \mathrm{~d}$ & $10.3 \pm 1.0^{\mathrm{a}}$ & $6.4 \pm 1.4^{\mathrm{d}}$ & $0.9 \pm 0.2^{\mathrm{a}}$ \\
$3 \mathrm{~d}$ & $11.7 \pm 1.0^{\mathrm{b}}$ & $8.8 \pm 0.7^{\mathrm{c}}$ & $0.8 \pm 0.1^{\mathrm{b}}$ \\
\hline
\end{tabular}

${ }^{\mathrm{a}-\mathrm{d}}$ Values within a column with no common superscript differed significantly, ranked from highest to lowest values $(P<0.05)$.

${ }^{1}$ Time $0=$ samples taken before drying-off (involution); $1,2,3 \mathrm{~d}=$ time after milking cessation.

${ }^{2}$ Samples of normal (reference) milk from mid-lactating cows (see Materials and Methods for description); lag time and $\mathrm{T}_{1 / 2}$ of bacterial growth and bacterial growth at the stationary phase in the reference samples did not differ from the respective values at $\mathrm{d} 0$ in the AFI cows by the paired $t$-test analysis.

to the mammary gland lumen (Shamay et al., 2002, 2003). Endotoxin (LPS) injection into the mammary gland induced disruption of the tight junctions, which is reflected by a dramatic increase in the concentrations of milk $\alpha-\mathrm{LA}$ and casein in blood shortly after treatment and rapid resumption of these components to preinjection levels $96 \mathrm{~h}$ later (McFadden et al., 1988). These findings sustain the concept that penetration of milk proteins into the blood is involved in inducement of massive recruitment of PMNL to the mammary gland and that adaptation to involution (opening of the tight junctions) might prevent the acute inflammatory response.

In general, our results are consistent with previous findings that show that milk yield before drying-off influences the involution process and can affect natural defense systems during the dry period (Oliver and Sordillo, 1989; Silanikove et al., 2005; Pezeshki et al., 2010; Leitner et al., 2011). According to the present study, the less effective antibacterial response in acute involution might be related to slow activation of the immune system as reflected by lower LDH activity and lower albumin and nitrite concentrations in ANI than in AFI cows. Recent studies have shown that albumin is produced by the mammary gland as part of its innate immune system (Shamay et al., 2005).

The plasmin system plays a critical role in inducing mammary gland involution in cows (Silanikove et al., 2005, 2013). Consistent with previous studies, we showed that activation of this system was slower in the AFI cows because of slower activation of the plasmin system (Silanikove et al., 2005). The plasmin system and activation of the immune system are interrelated by formation of proinflammatory casein-derived peptides (Silanikove et al., 2006; Leitner et al., 2011), which explains why involution proceeded faster in ANI than in AFI cows.

\section{Natural Involution Is Preceded by Metabolic Adaptive Responses}

Previous results led us to hypothesize that natural involution is preceded by metabolic and immune responses that make the involution process much more effective in terms of development of antimicrobial environment in the mammary gland lumen (Silanikove et al., 2005; Leitner et al., 2011, 2012). In the ANI cows, cessation of milking occurred without evidence of udder distension caused by milk stasis. In contrast, in the AFI cows, milk cessation was associated with considerable engorgement of the mammary gland and with vocalization, which suggests that these cows were in pain.

The gross composition of milk found in AFI cows was within the normal range for Israeli Holstein cows and this was also true for rennet clotting time and curd firmness (Merin et al., 2008). Changes in milk composition of the ANI cows indicated that their milk underwent substantial changes compared with that of the AFI cows. Changes in rennet clotting time, curd firmness, and proteose peptone content indicated that the casein micelles underwent considerable degradation. Importantly, following cessation of milking (i.e., inducement of involution), these parameters changed much faster in ANI than in AFI cows. In previous stud- 
ies, it was found that sudden and acute imposition of milk stasis resulted in more drastic reduction in lactose concentration and milk volume than in the secretion of fat and protein, which was reflected by increased concentrations of fat and protein in mammary secretions (Shamay et al., 2002, 2003). In cows adapted to heat stress (Silanikove et al., 2009) or when milk is sampled from AFI cows after 3 wk of cessation of milking (Silanikove et al., 2005), the reductions in fat and protein concentrations in mammary secretion exceeded that of lactose (i.e., the ratio of fat or protein to lactose concentration reduced to $<1$ ), as found in the ANI cows in the present experiment. Thus, the current results support the assumption that differences in gross composition of mammary secretions between the ANI and AFI cows reflect successful metabolic adaptations to the forthcoming involution only in ANI cows.

Increased casein degradation and proteose peptone content negatively affect rennet clotting time and curd firmness, which are important parameters of milk quality for cheese production (Merin et al., 2008; Fleminger et al., 2011, 2013). Prevention of casein hydrolysis in milk stored within the mammary gland in ANI cows most likely has an important physiological role; namely, prevention of formation of clots during milk stasis, thus preventing uncontrolled (necrotic) inflammation (Heegaard et al., 1994; Leitner et al., 2011; Silanikove et al., 2012).

Following induction of involution, the activity of the main proteolytic enzyme in milk (PL) increased more in ANI than in AFI cows because of enhanced conversion of PLG to PL (as reflected by decreasing PLG:PL ratios) and this was related to the greater increase in the concentration of proteose peptone in mammary secretions in ANI than in AFI cows (Table 2). Our results are consistent with previous studies noting that one of the roles of the PL system in milk is the formation of substances that prevent milk clotting during milk stasis or infection (Heegaard et al., 1994; Leitner et al., 2011; Silanikove et al., 2012). The involvement of the PAPLG-PL system in regulating milk secretion (Silanikove et al., 2000, 2005, 2006, 2009) and in the induction of mammary gland involution in rodents (Ossowski et al., 1979; Tonner et al., 2000) and ruminants (Shamay et al., 2002, 2003, 2005; Silanikove et al., 2005, 2006) is well established.

Milk production is an energy-demanding process (Kadzere et al., 2002). Reduction of citric acid secretion and its replacement by increased secretion of lactic and malic acids in ANI cows suggests that mammary gland metabolism is shifted toward glycolysis instead of mitochondrial oxidative metabolism, as was previously shown after endotoxin-induced inflammation (Silanikove et al., 2011). This shift under conditions of acute inflammation is regarded as an important mechanism that allows the organism to provide essential fuels to fight the infection. After milk cessation in ANI cows, changes in malate, lactate, and citrate concentrations suggest a shift from mitochondrial to cytosolic metabolism, which increased from d 0 to 3 in the ANI cows, whereas no such changes were noted in AFI cows. Thus, maintaining a high rate of metabolism in AFI cows during the first $3 \mathrm{~d}$ after milk cessation was most likely associated with considerable secretion of milk, which contributed to the dramatic engorgements of their udders. Thus, a shift to anaerobic metabolism may explain the lack of mammary gland engorgement in the ANI cows (Silanikove et al., 2011).

The increase in secretion of malic acid under anaerobic conditions is a new finding; however, it can be explained by classical enzymatic reaction of intermediate metabolic reactions in the cell cytoplasm (Silanikove et al., 2011). Leaking of mammary secretions from the teats because of measured intramammary pressure is a major cause of acquiring bacterial infection at the early period that follows milk cessation (Pezeshki et al., 2010). Thus, the metabolic adaptation linked to reduced energy metabolism of the mammary glands allows a reduction in mammary secretion and thus prevention of glandular engorgements and milk leakage.

\section{Natural-Like Involution Is Preceded by Immunological Adaptive Responses}

In general, PMNL are found mainly in the milk, whereas the mononuclear cells - lymphocytes and macrophages - are mostly found in the mammary tissues (Akers and Nickerson, 2011). Thus, the actual numbers of mononuclear cells involved in immunological processes in the mammary gland are, as expected, higher in the gland tissues than in the milk. With these limitations taken into account, we can suggest that the dramatic differences in leukocyte populations in the milk of ANI and AFI cows represent significant physiological or immunomodulatory differences.

Adaptations in the ANI cows may have enabled a more effective tissue remodeling cascade in response to the induction of involution, without the negative effects of neutrophilia. Evidence exists that macrophages and mammary gland epithelial cells are involved in clearing apoptotic cells in postpartum involution (Geske et al., 2002; Atabai et al., 2007; Leitner et al., 2007a; Monks and Henson, 2009), but little is known about the contribution of $\mathrm{CD}^{+}$and $\mathrm{CD} 8^{+} \mathrm{T}$ lymphocytes. Further research, such as additional subtyping of the $\mathrm{T}$ cells, cytokines secreted, and their involvement, is needed for better elucidation of the role of the acquired immune system in the involution process. Nevertheless, 
our results indicate that natural (or at least naturallike) involution is an interesting model for studying interactions between innate and acquired immunity, a subject of great interest in past years (Castriconi et al., 2004). Because T cells are characterized by long-term memory, it is tempting to speculate that these cells and milk antibodies serve to recognize a wide spectrum of pathogenic microbes, their toxins, and milk proteins that are repeatedly involved in the induction of an immune stress to the cardiovascular system.

\section{CONCLUSIONS}

Extensive selection of cows toward high milk yield affects the rate of mammary gland involution, particularly in stage I, in most cows. Metabolic and immunological adaptations toward the expected disengagement between dams and their offspring may be considered as an auto-defense mechanism. The large scale of cell apoptosis that characterizes mammary gland involution stage I requires effective clearance of the dead cells to avoid necrosis and uncontrolled inflammation. The tendency of modern cows to secrete great amounts of milk at drying-off considerably increases the risk of acquiring new intramammary infections soon after because of increased milk leakage and slower build-up of the mammary defense system. The metabolic and immunological adaptations described in cows approaching natural involution prevent this problem to a large extent. On the other hand, when mammary gland involution is induced in nonadapted animals, the response is more harmful and resembles the general response to wounding. As most modern dairy cows produce copious amounts of milk toward the end of the lactation, finding techniques to precipitously inhibit milk secretion at the induction of drying-off will be beneficial to dairy cows.

\section{ACKNOWLEDGMENTS}

This research was partially supported by a grant from the Israel Dairy Board (Yehud, Israel). The technical assistance of S. Bernstein (Department of Food Quality and Safety, Postharvest and Food Sciences, ARO, the Volcani Center, Israel) is highly appreciated.

\section{REFERENCES}

Akers, R. M., and S. P. Nickerson. 2011. Mastitis and its impact on structure and function in the ruminant mammary gland. J. Mammary Gland Biol. Neoplasia 16:275-289.

Atabai, K., D. Sheppard, and Z. Werb. 2007. Roles of the innate immune system in mammary gland remodeling during involution. J. Mammary Gland Biol. Neoplasia 12:37-45.
Bramley, A. J. 1976. Variations in suseptibility of lactating and nonlactating udders to infection with Escherichia coli. J. Dairy Res. $43: 205-211$.

Capuco, A. V., and R. M. Akers. 1999. Mammary involution in dairy animals. J. Mammary Gland Biol. Neoplasia 4:137-144.

Castriconi, R., M. Della Chiesa, and A. Moretta. 2004. Shaping of adaptive immunity by innate interactions. C. R. Biol. 327:533537.

Chuang, K. H., S. Altuwaijri, G. H. Li, J. J. Lai, C. Y. Chu, K. P. Lai, H. Y. Lin, J. W. Hsu, P. Keng, M. C. Wu, and C. S. Chang. 2009. Neutropenia with impaired host defense against microbial infection in mice lacking androgen receptor. J. Exp. Med. 206:1181-1199.

Clarkson, R. W. E., M. T. Wayland, J. Lee, T. Freeman, and C. J. Watson. 2004. Gene expression profiling of mammary gland development reveals putative roles for death receptors and immune mediators in post-lactational regression. Breast Cancer Res. 6:R92-R109.

Fleminger, G., H. Ragones, U. Merin, N. Silanikove, and G. Leitner. 2011. Chemical and structural characterization of bacteriallyderived casein peptides that impair milk clotting. Int. Dairy J. 21:914-920.

Fleminger, G., H. Ragones, U. Merin, N. Silanikove, and G. Leitner. 2013. Low molecular weight peptides generated by hydrolysis of casein impair milk clotting parameters. Int. Dairy J. 30:74-78.

Geske, F. J., J. Monks, L. Lehman, and V. A. Fadok. 2002. The role of the macrophage in apoptosis: Hunter, gatherer, and regulator. Int. J. Hematol. 76:16-26.

Heegaard, C. W., T. Christensen, M. D. Rasmussen, C. Benfeldt, N. E. Jensen, K. Sejrsen, T. E. Petersen, and P. A. Andersen. 1994. Plasminogen activators in bovine-milk during mastitis, an inflammatory disease. Fibrinolysis Proteol. 8:22-30.

Hillerton, J. E., J. Cooper, and J. Morelli. 2007. Preventing bovine mastitis by a postmilking teat disinfectant containing acidified sodium chlorite. J. Dairy Sci. 90:1201-1208.

Kadzere, C. T., M. R. Murphy, N. Silanikove, and E. Maltz. 2002. Heat stress in lactating dairy cows: A review. Livest. Prod. Sci. 77:59-91.

Larsen, T. 2005. Determination of lactate dehydrogenase (LDH) activity in milk by a fluorometric assay . J. Dairy Res. 72:209-216.

Leitner, G., M. Anug, U. Merin, and N. Silanikove. 2007a. Pregnancy obstructs involution stage II of the bovine mammary gland: General biological implications. Isr. J. Vet. Med. 62:91-95.

Leitner, G., S. Jacoby, E. Maltz, and N. Silanikove. 2007b. Casein hydrolyzate intramammary treatment improves the comfort behavior of cows induced into dry-off. Livest. Sci. 110:292-297.

Leitner, G., O. Krifucks, U. Merin, Y. Lavi, and N. Silanikove. 2006. Interactions between bacteria type, proteolysis of casein and physico-chemical properties of bovine milk. Int. Dairy J. 16:648-654.

Leitner, G., U. Merin, O. Krifucks, S. Blum, A. L. Arivas, and N. Silanikove. 2012. Effects of intra-mammary bacterial infection with coagulase negative staphylococci and stage of lactation on shedding of epithelial cells and infiltration of leukocytes into milk: Comparison among cows, goats and sheep. Vet. Immunol. Immunopathol. 147:202-210.

Leitner, G., U. Merin, and N. Silanikove. 2011. Effects of glandular bacterial infection and stage of lactation on milk clotting parameters: Comparison among cows, goats and sheep. Int. Dairy J. $21: 279-285$.

Lund, L. R., J. Romer, N. Thomasset, H. Solberg, C. Pyke, M. J. Bissell, K. Dano, and Z. Werb. 1996. Two distinct phases of apoptosis in mammary gland involution: Proteinase-independent anddependent pathways. Development 122:181-193.

Lynch, E. M., B. Earley, M. McGee, and S. Doyle. 2010. Effect of abrupt weaning at housing on leukocyte distribution, functional activity of neutrophils, and acute phase protein response of beef calves. BMC Vet. Res. 6:39.

McFadden, T. B., R. M. Akers, and A. V. Cappuco. 1988. Relationships of milk proteins in blood with somatic cell counts in milk of dairy cows. J. Dairy Sci. 71:826-834.

Merin, U., G. Fleminger, J. Komanovsky, N. Silanikove, S. Bernstein, and G. Leitner. 2008. Subclinical udder infection with Streptococ- 
cus dysgalactiae impairs milk coagulation properties: The emerging role of proteose peptones. J. Dairy Sci. Technol. 88:407-419.

Metcalf, D., L. Robb, A. R. Dunn, S. Mifsud, and L. DiRago. 1996. Role of granulocyte-macrophage colony-stimulating factor and granulocyte colony-stimulating factor in the development of an acute neutrophil inflammatory response in mice. Blood 88:37553764 .

Monks, J., F. J. Geske, L. Lehman, and V. A. Fadok. 2002. Do inflammatory cells participate in mammary gland involution? J. Mammary Gland Biol. Neoplasia 7:163-176.

Monks, J., and P. M. Henson. 2009. Differentiation of the mammary epithelial cell during involution: Implications for breast cancer. J. Mammary Gland Biol. Neoplasia 14:159-170.

Nilsen-Hamilton, M., Q. S. Liu, J. Ryon, L. Bendickson, P. Lepont, and Q. Chang. 2003. Tissue involution and the acute phase response. Ann. N. Y. Acad. Sci. 995:94-108.

NRC. 2001. Nutrient Requirements of Dairy Cattle. 7th ed. National Academies Press, Washington, DC.

Oliver, S. P., and L. M. Sordillo. 1989. Approaches to the manipulation of mammary involution. J. Dairy Sci. 72:1647-1664.

Ossowski, L., D. Biegel, and E. Reich. 1979. Mammary plasminogen activator - Correlation with involution, hormonal modulation and comparison between normal and neoplastic. Cell 16:929-940.

Pezeshki, A., A. V. Capuco, B. De Spiegeleer, L. Peelman, M. Stevens, R. J. Collier, and C. Burvenich. 2010. An integrated view on how the management of the dry period length of lactating cows could affect mammary biology and defence. J. Anim. Physiol. Anim. Nutr. 94:e7-e30.

Piantoni, P., P. Wang, J. K. Drackley, W. L. Hurley, and J. J. Loor. 2010. Expression of metabolic, tissue remodeling, oxidative stress, and inflammatory pathways in mammary tissue during involution in lactating dairy cows. Bioinform. Biol. Insights 4:85-97.

SAS Institute. 1988. SAS/STAT 9.2 User's Guide. 2nd ed. SAS Institute, Cary, NC.

Shamay, A., R. Homans, Y. Fuerman, I. Levin, H. Barash, N. Silanikove, and S. J. Mabjeesh. 2005. Expression of albumin in nonhepatic tissues and its synthesis by the bovine mammary gland. J. Dairy Sci. 88:569-576.

Shamay, A., F. Shapiro, H. Barash, I. Bruckental, and N. Silanikove. 2000. Effect of dexamethasone on milk yield and composition in dairy cows. Ann. Zootech. 49:343-352.

Shamay, A., F. Shapiro, G. Leitner, and N. Silanikove. 2003. Infusions of casein hydrolyzates into the mammary gland disrupt tight junction integrity and induce involution in cows. J. Dairy Sci $86: 1250-1258$.
Shamay, A., F. Shapiro, S. J. Mabjeesh, and N. Silanikove. 2002. Casein-derived phosphopeptides disrupt tight junction integrity, and precipitously dry up milk secretion in goats. Life Sci. 70:27072719.

Shapiro, F., and N. Silanikove. 2010. Rapid and accurate determination of D- and L-lactate, lactose and galactose by enzymatic reactions coupled to formation of a fluorochromophore: Applications in food quality control. Food Chem. 119:829-833.

Silanikove, N., U. Merin, and G. Leitner. 2006. Physiological role of indigenous milk enzymes: An overview of an evolving picture. Int. Dairy J. 16:533-545.

Silanikove, N., A. Rauch-Cohen, F. Shapiro, A. Arieli, U. Merin, and G. Leitner. 2012. Lipopolysaccharide challenge of the mammary gland in cows induces nitrosative stress that impairs milk oxidative stability. Animal 6:1451-1459.

Silanikove, N., A. Rauch-Cohen, F. Shapiro, S. Blum, A. Arieli, and G. Leitner. 2011. Lipopolysaccharide challenge of the mammary gland in bovine induced a transient glandular shift to anaerobic metabolism. J. Dairy Sci. 94:4468-4475.

Silanikove, N., A. Shamay, D. Shinder, and A. Moran. 2000. Stress down regulates milk yield in cows by plasmin induced beta-casein product that blocks $\mathrm{K}^{+}$channels on the apical membranes. Life Sci. 67:2201-2212.

Silanikove, N., and F. Shapiro. 2011. Rapid and accurate determination of malate, citrate, pyruvate and oxaloacetate by enzymatic reactions coupled to formation of a fluorochromophore: Application in colorful juices and fermentable food (yogurt, wine) analysis. Food Chem. 129:608-613.

Silanikove, N., F. Shapiro, and G. Leitner. 2005. Role of xanthine oxidase, lactoperoxidase and $\mathrm{NO}$ in the innate immune system of mammary secretion during active involution in dairy cows: Manipulation with casein hydrolysates. Free Radic. Biol. Med. 38:1139-1151

Silanikove, N., F. Shapiro, U. Merin, and G. Leitner. 2013. Tissue-type plasminogen activator and plasminogen embedded in casein rule its degradation under physiological situations: Manipulation with casein hydrolysate. J. Dairy Res. 80:227-232.

Silanikove, N., F. Shapiro, and D. Shinder. 2009. Acute heat stress brings down milk secretion in dairy cows by up-regulating the activity of the milk-borne negative feedback regulatory system. BMC Physiol. 9:13.

Tonner, E., G. J. Allan, and D. J. Flint. 2000. Hormonal control of plasmin and tissue-type plasminogen activator activity in rat milk during involution of the mammary gland. J. Endocrinol. 167:265273. 